\title{
Birbal Sahni and His Father Ruchi Ram: Science in Punjab Emerging from the Shadows of the Rāj
}

\author{
Ashok Sahni* \\ (Received 15 May 2018; revised 24 May 2018)
}

\begin{abstract}
Panjab has always been at the crossroads of change. At the end of the nineteenth century with opening up of the markets of the west and the pervasive atmosphere of British colonialism, the demographic composition of this state changed and an aspirational middle class was born. One of the families that epitomised this fledgling social strata and contributed to the development of science and industry was headed by Ruchi Ram Sahni. He became the first Indian meteorologist while acquiring a degree from Presidency College, Kolkata in 1885 where he came in touch with some great minds of his times. This experience stood him in good stead in his later life. He visited the University of Manchester during 1914 just as First World War was breaking out. He managed to write two papers that were communicated by Lord Rutherford in 1915 and 1917. His son Birbal meanwhile had reached Cambridge and was completing his Tripos there, specializing in Botany. Birbal loved his work and wrote several papers while still in the United Kingdom establishing himself as one of the leading botanists of his times. He worked briefly at Banaras Hindu University and Panjab University before settling down to a Professorship at Lucknow University. During this time through his own research and the work of his colleagues and students, he raised the status of the little known subject of Palaeobotany to global recognition. Unfortunately barely a week after establishing a research institute that now bears his name, he died at any early age with dreams unfulfilled.
\end{abstract}

Key words: Birbal Sahni, Colonial Punjab, Research profiles, Ruchi Ram Sahni, Science.

\section{InTRODUCTION}

There were many persons who contributed intellectually to the growth and development of Panjab during the latter part of $19^{\text {th }}$ Century and early part of the $20^{\text {th }}$ century. As Panjab changed, a new breed of people emerged who were willing to discard their traditional past and embrace new ideas of life and religion influenced by colonial life. This led to the resurgence of science at the end of the $19^{\text {th }}$ century coinciding with the establishment of the University of Panjab at Lahore in 1882. The time also registered the rise of an aspirational middle class in a country steeped in a feudal set up. It further marked the emergence of a small group of Indians who were both nationalists and rationalists in a country where the majority of people still relied on magical cures and amulets and the bigotry of the sages and peers that dotted the landscape.

Here we focus on a family that put great value on science and the scientific temperament and the efforts of the head of this family, Ruchi Ram Sahni. A self-made man, he first established himself academically and then through entrepreneurship, created an industrial base so that he could educate his children and send them to the United Kingdom for higher studies. One son, Birbal Sahni, excelled in his field of endeavour, and was made a Fellow of the Royal Society in 1936.

\footnotetext{
* Professor Emeritus, Centre of Advanced Study in Geology, Panjab University, Chandigarh-160014, Mailing Address: 98 Mahatma Gandhi Marg, Lucknow; Email: ashok.sahni@gmail.com
} 


\section{Ruchi Ram Sahni (5 ${ }^{\text {TH }}$ APRIL 1863 - $3^{\text {Rd }}$ June 1948)}

The Sahni clan comes from Bhera, a medieval town located on the eastern bank of the Jhelum River. Ruchi Ram and his forefathers were part of an old and established business family who were basically money lenders and had started trading in goods during the latter part of the nineteenth century as markets of the western world opened up. Tragedy struck one day and the family lost most of their wealth. This meant that Ruchi Ram had to fend for himself financially from a very young age. This toughened him and gave him the confidence to charter his own path through school and later college mainly on the basis of merit scholarships, (Burra, 2017; Sehgal and Mohanti 1994).

Ruchi Ram was different. While still a student at high school he became a Brahmo Samāji. So vexed and angry was his mother at her son for this decision, that she never set foot in her son's home after that. But he was adamant. As a brahmo, he came in contact with like minded free thinkers which included the father of (later Sir) S S Bhatnagar. The bond with the family that started at Bhera endured till the very end (Kochhar, 2013). Ruchi Ram joined the fledgling Panjab University soon after its establishment and went on to get a Bachelors degree in 1884 . He then moved on to Presidency College in Kolkata where he was obtained a M.A. in Physics and Chemistry degree in 1885, (Kochhar, 2013). While still a student there he was selected as a meteorologist in 1885 at the tender age of 22 years and was allowed to study as well as complete his responsibilities as the Meteorologist Assistant, being the first Indian to do so. But, his mind and heart were always in academics and when he got an opportunity to join Government College at Lahore as an Assistant Professor of Chemistry in 1886, he accepted the offer and worked there from 1887 to 1918 . He took to his job seriously often running into conflict with his colleagues. In mid-career he decided to leave for Heidelberg in 1914. First World War had just started and his German Professor and guide Fajhans suggested that he leave immediately for Rutherford's lab at the University of Manchester. Ruchi Ram spent nearly two years at Manchester (1914- 1915) and worked with some of the greatest minds assembled there. He wrote two papers (Sahni, 1915, 1917) communicated by Rutherford himself and whom he always regarded as a true guide and friend (Sahni, 1937). During his stay at Manchester he was greatly helped by his son Birbal Sahni who was already in Cambridge completing his Tripos degrees (Fig.1). In fact it is more than plausible that the topic of research Ruchi Ram had chosen to undertake at Manchester, namely the record of alpha, beta and gamma particles on photographic plates was influenced by his son's expertise in photography. Some indications that this may have been the case come from material recovered from Birbal Sahni's home in Lucknow in 2016 in the form of a photographic plate of alpha particles with a legend written in son's handwriting.

\section{Birbal Sahni \\ (14 ${ }^{\mathrm{TH}}$ November 1891 - 10 $^{\mathrm{TH}}$ April 1949)}

Birbal and his father enjoyed a warm relationship from the very beginning. Ruchi Ram

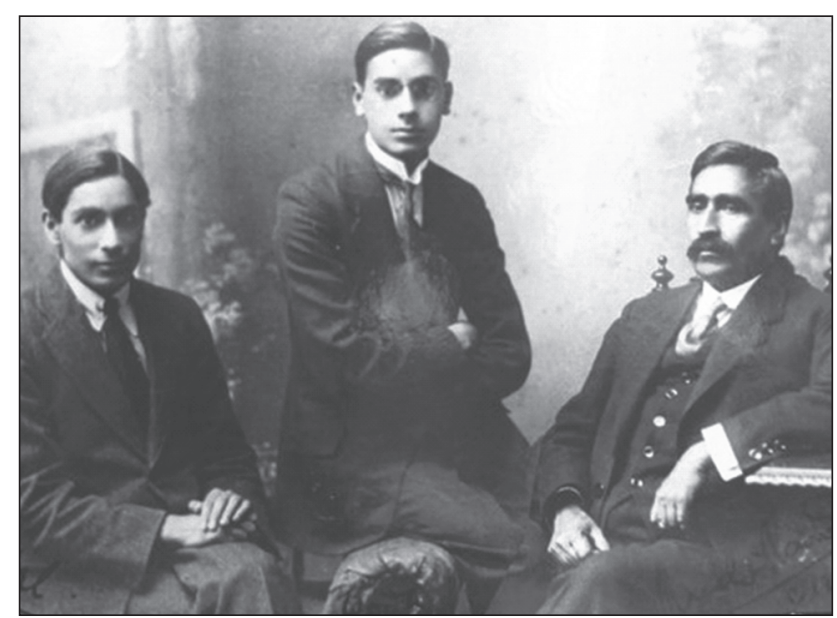

Fig. 1. In Manchester 1914 with two of his sons, Bodh Raj (centre) and Birbal (left). (Courtesy: Collection of Birbal Sahni at his Lucknow Residence) 
believed in 'hardening' his children against the rigors of life. Every summer, he set out with his sons to remote parts of the Himalaya. Some of these traverses are recorded (Mulk Raj Sahni 1982, unpublished autobiography) and had a great influence on the minds of those children who accompanied him. Between 1907 to 1911, the father and his sons visited Pathankot, Rohtang, Narkanda, and Chini Pass; later, Srinagar and Amarnath and in 1911, the Machoi Glacier and Jozila Pass. Birbal and his younger brother were always ready for adventure and both turned to science one a botanist and the other a geologist (Sahni, 2004). While still young, Birbal made innumerable trips to the Salt Range-Potwar Plateau region situated near his hometown Bhera. Trips to the greater Himalaya had a great influence on young Birbal and his love for botany was born. Armed with Hooker's Flora of British India, these travels whetted young Birbal's appetite for identifying his specimens from the High Himalaya some of which are reposited at Kew Gardens. Even on his return from England, Birbal's love for the Himalaya haunted him. In 1920 in company of S R Kashyap, he visited Chamba, Leh, Baltal and Amarnath and in 1923 Uri, Poonch-and Gulmarg.

Unlike his other siblings who were mostly schooled at home, Birbal attended the Mission and Central Model School Lahore. Mulk Raj Sahni (1982, unpublished autobiography) mentions that great emphasis was placed on home schooling as well. Latin and Sanskrit were high on the list of favoured subjects. The home library included Hitopadesh, as well as books on Astronomy, Science and the historical romances of Walter Scott and Cervantes. There was a special teacher who taught drama. It was with this background that young Birbal prepared for his academic life at Cambridge University before he had turned 20 years. He passed the Intermediate Science in flying colours and topped the province in Sanskrit.

He completed in 1911 a B. Sc. degree from Government College, Lahore where he came under the influence of S R Kashyap and decided to opt for an academic career in Botany rather than pursue the Indian Civil Services which his father was keen on. He left for England soon after 1911 and took his Natural Science Tripos 1 from Emmanuel College Cambridge in the First Class and then in 1915 the Natural Science Tripos 2 from the same college. Two years later he received a B S degree from the University of London though there is some controversy as to the exact date. In 1919-1920, he was appointed Professor at Benares Hindu University, Varanasi and later Professor at University of Punjab, Lahore. 1920 was a landmark year for Birbal. This was the year when he also got married to Savitri Suri. In 1921, he was appointed Professor at Lucknow University in Departments of Botany and Geology- the two main ingredients in the recipe for making a palaeobotanist! Lucknow University was at its acme for academic excellence and he settled down at the University building a band of colleagues and students who laid the foundation of the field of Palaeobotany.

\section{RESEARCH}

His research canvas was large both spatially and temporally. He concentrated on the Himalayan region as well as Peninsular India in central and in the eastern region, (Hamshaw, 1950). He worked on plant fossils from the Cambrian (500 million years) to the Recent (Sahni, 1945). His expertise on plant anatomy was acknowledged by the peers of his times and he was given the task of updating the major text book by Lawson on botany (Sahni and Willis, 1919). Throughout the course of his academic career he showed his mastery in anatomical details and was thus able to place several fossils in a systematic position. He used his commanding knowledge of botany (taxonomy) to compare anatomical features between recent and fossil plants. For example, he was able (Sahni, 1925) to show from recent plant collections made in New Caledonia 
in 1914, affinities to very primitive plants known as the Psilotales (400-300 million years).

His work was not only confined to fossils. He was able to calculate uplift of mountain ranges based on the ecology of the plant fossils. For example, if plants grew only a certain altitude but were found as fossils at much elevated heights where they could not have grown, this implied a mismatch only which could only be explained by tectonic uplift. He discovered an ancient mint near Rohtak and wrote extensively about his finds (Sahni, 1936). He wrote theoretical papers on the grand ideas of his times, namely 'Continental Drift' (Sahni, 1936) and 'Ontogeny recapitulates Phylogeny’ (Sahni, 1925). He excelled in photography and botanical techniques and was obsessed with precision! He even left money to his laboratory preparator in his will!

\subsection{A Brief Outline of his Major Research milestone}

His DSc. was obtained at the University of London and was based on his observation of how the seed was carried in conifers. He studied a rare conifer Acmopyle pancheri and the way the seed was placed either on the axis or in leaf groups (Sahni, 1920). While studying the structure of the ovules in conifers he came to the conclusion that the seeds were born either directly on the axis or some other axis-modified structure, a condition which he named as 'stachyspermous'. This was in contrast to other gymnosperms which usually had the seeds growing in leaf groups, and hence 'phyllospermous'. This work still endures the test of time and he is regarded as one of the cornerstone of his coming of age as an established botanist. In the same year his interest turned to Indian fossil plants and along with his guide, A C Seward, he published (Sahni and Seward, 1920) a monograph on Gondwana plants and their taxonomic revision. Other works followed, (Sahni, 1926, 1930 and 1935).

In 1932, Sahni made another landmark discovery that of the Bennetitalean taxon
Williamsonia sewardi. It is this plant and the reconstruction of the whole vegetative system that made him famous (Sahni, 1932). Earlier in 1929 he was awarded the DSc from Cambridge and was appointed a Vice President at the Fifth International Botanical Congress held next year at Cambridge.

The next major landmark was his discovery of a new type of fossil gymnosperm from the Jurassic Rajmahal Hills (now in Jharkhand) (Fig.2). The family known as the Pentoxyleae was discovered from the village of Nipania. The form had already been described by different authors based on the seed structure, internal structure of the wood and the leaves. Sahni's acumen laid in seeing that all these differently described vegetative parts belonged to the same plant (Sahni, 1948). The Pentoxylaceae was defined by him and I quote:

Pentoxylaceae while in their seed attachment they are clearly Stachyosperms (coniferophytes), and they also have a coniferous type of secondary wood, their stomatal structure is fundamentally Bennettitalean, the vascular anatomy of their leaves is truly cycadean, and the general anatomy of the stem is unique (B Sahni, 1948).

Sahni then diverted his attention to the flora found in beds that intervene between the

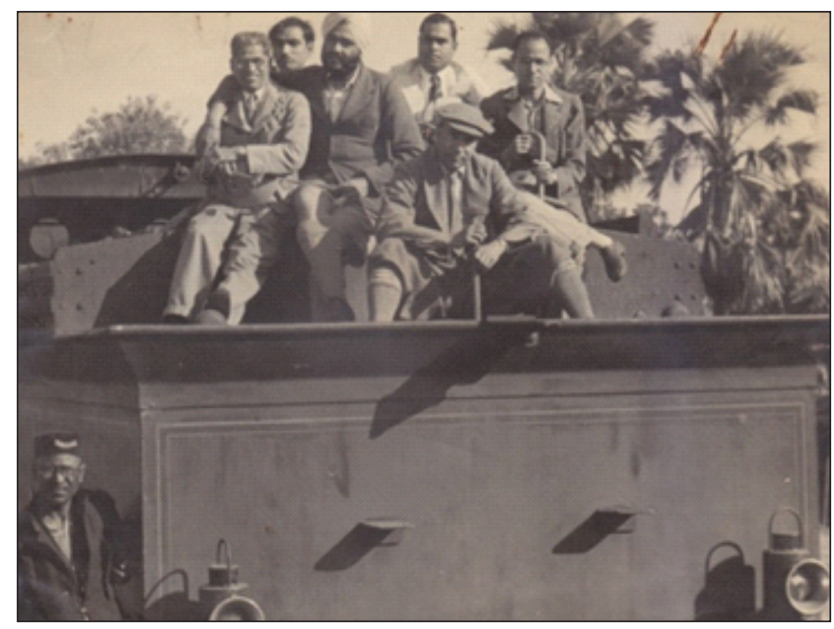

Fig. 2. Sitting in the coal truck of a steam engine on his way to the Jurassic Rajmahal localities of Jharkhand. Taken from M.R. Sahni's personal photograph collection. The man wearing a cap is Birbal Sahni. 
Deccan volcanic lava flows and known in common terms as the Intertrappeans (Sahni 1934, in 3 parts). At that time there was a general controversy whether the Intertrappean flora was Cretaceous or Tertiary in age. There were few reference points as India was isolated and distanced from standard floral assemblages both in the Cretaceous and in the earliest Tertiary. On the basis of the collected flora, he opted for a Tertiary age (Sahni, 1937). Later work now shows that the Deccan eruptive phase straddles the Cretaceous Tertiary boundary and he was only partially correct in his inferences.

Apart from fossil plants, Sahni (1936, 1939) delved into larger issues. He found a mint near a mound at Rohtak with intact coins dating back to about $100 \mathrm{BCE}$ when the Yaudhayas of Bahodhasakas ruled in what now is the Punjab region. The coins are made of bronze and not of copper and inscribed with the Brahmi script. The image on the coins includes that of the Humped Bull Bos indicus. Some of the coins still lie in the pristine moulds! Sahni expanded on his finds by writing another paper in the same year (Sahni, 1936) and a more elaborate one later on casting techniques (Sahni, 1939).

The other "larger" issue which interested him was the rise of the Himalaya and how palaeobotanical evidence could throw light on amount or rate of uplift. His first work in this direction was in one of his favoured destinations, the Karewas of Kashmir (Sahni 1936). This work still stands out for its novelty and innovation. Later he gave a holistic view of the Himalayan uplift and the consequences on human cultures, (Sahni, 1939).

During the latter part of his career he focussed on the Saline Series, a sequence of rocks located not far from his original hometown of Bhera (Sahni and Trivedi, 1945). Sahni held that the age of the rocks was Tertiary based on the variety of fossils recovered. His identifications as usual were correct but he did not take into account that the salt beds of the Saline Series could later incorporate fossils leaked from younger sediments. Nonetheless, these studies helped other workers to work out the correct sequence based on stratigraphy and other fossils.

He was awarded the Fellowship of the Royal Society in 1936.

During the late 1940's, it was his mission to establish a research institute concentrating on palaeobotanical studies. He succeeded in the end and the Foundation Stone of the Institute laid by Pandit Jawaharlal Nehru on April 3, 1949. His joy however was short lived and he died soon after. His premature death prevented him assuming office of one of the Honorary Presidents of the Seventh International Botanical Congress in Stockholm (1950). His other awards and honours include the Presidentship of the National Academy of Sciences; the Barclay Medal of the Royal Asiatic Society for Biological Sciences and the Sir C R Reddy Prize for Natural Sciences 1947.

Birbal Sahni was not only loved and admired for his scientific endeavours but also was a caring husband, much loved by colleagues and students (Fig.3). His younger sibling, a geologist has penned the lines below as an eulogy for a beloved brother (Sahni, 1952).

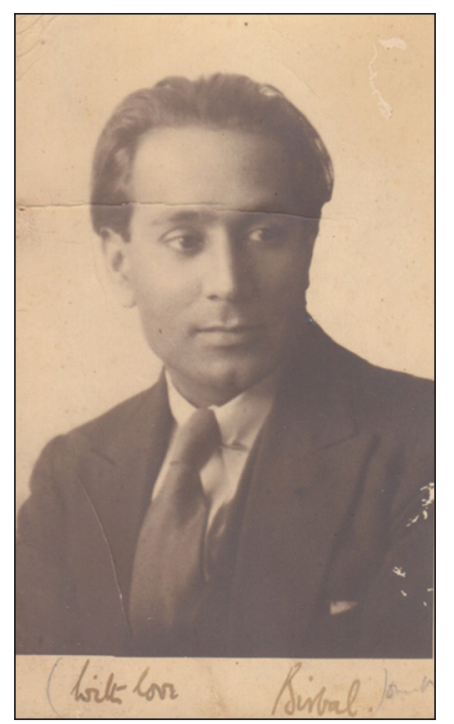

Fig. 3. Birbal Sahni, Vienna, sometime in the 1940s. Taken from M R Sahni's personal photograph collection. 


\author{
Who knows the Final End? \\ Who Knows the Morning Glow? \\ The Darkest depths of Night \\ Unfold the Brightest Day. \\ The Ripened Acorn tumbles \\ Always but to Grow. \\ Were Life and Death not Moulded \\ In one Common Clay?
}

\section{BIBIOGRAPHY}

Burra, N. A Memoir of pre-Partition Punjab. Ruchi Ram Sahni 1863-1948, Oxford University, 2017, pp.1-354.

Hamshaw Thomas, H. Birbal Sahni, 1891-1949, Biographical Memoirs of the Fellows of the Royal Society, 719 (1950):265-277

Kochhar, R. Professor Ruchi Ram Sahni (1863-1948): A scientific biography, Physics News, 43 .1: 19-35.

Kochhar, R. The early Indian Academy of Sciences and the Bhera connection, Current Science, 104.11 (2013): 1566.

Sahni, A. The Boyhood of Birbal Sahni-taking to science in $19^{\text {th }}$ Century Panjab, Resonance: (2004):42-49.

Sahni, B and Willis, J C. Lawson's text book of botany, Univ. Tut. Press London, 1919.

Sahni, B. On the structure and affinities of Acmopyle Pancheri Pilger. Phil. Trans. B, 210, (1920): 253-310.

Sahni, B and Seward A C. Indian Gondwana plants: a revision. Mem. Geol. Surv. Ind. Pal. Ind. 7 1(1920): $1-40$.

Sahni, B. On Tmesipteris Vieillardi Dangeard, an erect terrestrial species from New Caledonia, Phil. Trans. B, 213 (1925): 143-170.

Sahni, B. The ontogeny of vascular plants and the theory of recapitulation. J. Ind. Bot. Soc. 4.6 (1925): 202-216

Sahni, B. The southern fossil floras-A study in plant geography of the past. (Pres. Add.) $13^{\text {th }}$ Ind. Sci. Cong. Bombay, 1926, pp. 229-254.

Sahni, B. The relation of the late Palaeozoic floras to the early Mesozoic floras, Proc. $5^{\text {th }}$ Int. Bot. Cong. Cambridge, 1930, pp.503-504.

Sahni, B. A petrified Williamsonia (W. Sewardiana, sp. nov.) from the Rajmahal Hills, India. Mem. Geol. Surv. Ind. Pal. Ind. 20.3 (1932): 1-9.
Sahni, B. The silicified flora of the Deccan Intertrappean Series, Pt. I (General), Proc. $21^{\text {st }}$ Ind. Sci. Cong. Bombay, 1934, pp. 316-317.

Sahni, B 1934. The silicifled flora of the Deccan Intertrappean series, Pt. II. Gymnospermous and angiospermous fruits. Proc. of $21^{\text {st }}$ Ind. Sci. Cong. Bombay, 1934, pp. 317-318.

Sahni, B. and Srivastava, B P. The silicified flora of the Deccan Intertrappean Series.Pt. III. Sausarospermum Fermori. gen. et sp. nov. Proc. of $21^{\text {st }}$ Ind. Sci. Cong. Bombay, 1934, p. 318.

Sahni, B. The Glossopteris flora in India. Proc. 6th Int. Bot. Cong. Amsterdam, 2, (1935): 245-248.

Sahni, B. Antiquities from the Khokra Kot mound at Rohtak in the Jumna Valley. Curr. Sci. 4.11, (1936):7 96-801.

Sahni, B. The Karewas of Kashmir, Curr. Sci. 5, (1936):1016.

Sahni, B. The Himalayan uplift since the advent of Man: its culthistorical significance, Curr. Sci. 5.1 (1936): 1016.

Sahni, B. A clay seal and sealing of the Sunga period from the Khokra Kot mound (Rohtak), Curr. Sci. 5.2 (1936): 80-81.

Sahni, B. Wegener's theory of continental drift in the light of palaeobotanical evidence, J. Ind. Bot. Soc. 15.5 (1936): 319-322.

Sahni, B. The Gondwana affinities of the Angara flora in the light of geological evidence, Nature, 138.3495 (1936): 720-721.

Sahni, B. The age of the Deccan Trap. (General Discussion), Proc. of $24^{\text {th }}$ Ind. Sci. Cong. Hyderabad, 1937, pp. 464-468.

Sahni, B. Wegener's theory of continental drift with reference to India and adjacent Countries, (General discussion), Proc. of $24^{\text {th }}$ Ind. Sci. Cong., 1937, pp. 502-506.

Sahni, B . The eastward opening of the Himalayan geosyncline into the Pacific Ocean, Proc. of $6^{\text {th }}$ Pacific Sci. Cong., 1939, pp. 241-244

Sahni, B. Age of the Saline Series in the Salt Range, Punjab. Nature, 153 (1944): 462.

Sahni, B. The technique of casting coins in ancient India, Mem. Numis. Soc. Ind., 1 (1945):1-68.

Sahni, B and Trivedi, B S. Age of the Saline Series in the Salt Range of the Punjab, Nature, 155 (1945): 76. 
Sahni, B. The Pentoxyleae: a new group of Jurassic gymnosperms from the Rajmahal Hills of India, Bot. Gaz. 110.1(1948): 47-80.

Sahni, M R. Birbal Sahni: A Biographical Sketch, Palaeontological Society of India, 1952, pp. 1-14.

Sahni, M R. Landmarks and Strandlines : An autobiographical sketch, Unpublished ms. 1982

Sahni, R R. The photographic action of $\alpha, \beta$, and $\gamma$ rays. Philosophical Magazine, Series 6, 29, 174(1915): 836841.
Sahni, R R. The scattering of $\alpha$ particles by gases. Philosophical Magazine, 6, 33, 95, (1917): 290295

Sahni, R R. Lord Rutherford: A personal Tribute by one of his pupils, Current Science, 6: (1937): 249-250.

Sehgal, N K and Mohanti, S. (eds). Memoirs of Ruchi Ram Sahni: Pioneer of Science Popularisation in Punjab, Vigyan Prasar, New Delhi, 1994, pp. 1-263. 